DE

M E D I C I N A

T R O P I C A L

$\mathrm{DE}$

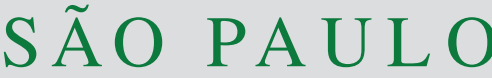

JOURNAL OF THE SÃO PAULO INSTITUTE OF TROPICAL MEDICINE

${ }^{1}$ Fundação Oswaldo Cruz, Instituto Oswaldo Cruz, Laboratório de Biologia e Parasitologia de Mamíferos Silvestres Reservatórios, Rio de Janeiro, Rio de Janeiro, Brazil

Correspondence to: Marta Júlia Faro Fundação Oswaldo Cruz, Instituto Oswaldo Cruz, Laboratório de Biologia e Parasitologia de Mamíferos Silvestres Reservatórios, Avenida Brasil, 4365, CEP 21040-900, Rio de Janeiro, RJ, Brazil Tel: +55 21 2562-1372

E-mail: martajulia.ioc.fiocruz@gmail.com

Received: 24 April 2018

Accepted: 27 July 2018

\section{A survey of freshwater and terrestrial snails in a predominantly urban municipality of Rio de Janeiro State, Brazil, with emphasis on human parasites vectors}

\author{
Tassiana Pereira Tomaz ${ }^{1}$, Rosana Gentile', Juberlan Silva Garcia', Bernardo \\ Rodrigues Teixeira1', Marta Júlia Faro'
}

\section{ABSTRACT}

Many snail species act as intermediate hosts of helminths that transmit diseases to humans and animals, such as schistosomiasis and angiostrongyliasis. São Gonçalo, a mostly urban municipality in Rio de Janeiro State, Brazil, has undergone fundamental environmental impacts, which favor the establishment of a range of diseases, for which snails act as the intermediate hosts of the etiological agents. In the present study, freshwater and terrestrial snail populations were surveyed in different environments within five city districts, and the presence of helminths was determined in the collected specimens. A total of 287 individuals were collected, six species from freshwater environment, Pomacea sp. (Ampullariidae), Melanoides tuberculata (Thiaridae), Biomphalaria tenagophila (Planorbidae), Dysopeas muibum (Subulinidae), Physa marmorata, and Physa acuta (Physidae), and two from terrestrial environment, Achatina fulica (Achatinidae) and Bradybaena similaris (Bradybaenidae). Snails were found in only two districts, Centro, an urban area, and Ipiiba, a rural area. Thirteen percent of the specimens of A. fulica eliminated larvae of the nematode Angiostrongylus cantonensis. None of the analyzed freshwater snails contained helminths. The most abundant and frequent snails were $B$. tenagophila, $M$. tuberculataand $A$. fulica, and the latter two species are exotic. The disturbance and degradation of natural areas adjacent to residential zones favor the proliferation of helminths, jeopardizing the local residents health. The abundance of A. fulica and B. tenagophila in the study area reinforces the need for a continuous and systematic monitoring of the snail fauna in this region.

KEYWORDS: Achatina fulica. Angiostrongyliasis. Biomphalaria tenagophila. Snail. Schistosomiasis. Freshwater snails. Terrestrial snails

\section{INTRODUCTION}

Snails are of considerable ecological importance due to their contribution to the fragmentation and decomposition of organic matter, which supports nutrient cycling. The abundance and diversity of snails in an ecosystem are determined by a variety of factors, such as habitat availability and pollution ${ }^{1}$.

Limnic snails can be found in lotic habitats, such as stream and ditches, and lentic environments, including ponds and even puddles. In lotic habitats, the current flow is an important determinant of snails diversity, because, in general, backwater areas favor a greater abundance of some species. In freshwater environments, some species, in particular those of the families Lymnaeidae, Planorbidae and Thiaridae, are of special interest due to their role as intermediate hosts of a number of helminths whose definitive hosts are humans or domestic animals². In Brazil, 
limnic snails of the genus Biomphalaria represent a serious public health issue, given that they are intermediate hosts of Schistosoma mansoni, the etiologic agent of mansonic schistosomiasis. Transmission foci of helminthic diseases, which have snails as intermediate hosts, often have similar ecological characteristics, such as location in peridomicile or rural areas lacking basic sanitation ${ }^{3,4}$.

Terrestrial snails also play an important ecological role in the recycling of soil nutrients and dispersal of spores and seeds through their mucus or feces. Some species are exploited by humans as a source of food, and others are employed in the biological control of weeds, although many are agricultural pests ${ }^{3}$. As for the limnic species, some terrestrial snails of the families Achatinidae and Bradybaenidae may act as intermediate hosts of helminths that parasitize humans and domestic animals ${ }^{5-7}$, including the nematode Angiostrongylus cantonensis, which can parasitize the human central nervous system, causing eosinophilic meningitis.

São Gonçalo is the second most populated municipality of the Brazilian State of Rio de Janeiro, which encompasses a large and heterogeneous area that has undergone a range of environmental impacts. Most of the population has little access to information on environmental issues, and has no access to basic public sanitation services. In addition, a large number of commuters pass through the urban zone every day. Rapid population growth in recent decades has led to unregulated housing development in risk areas, such as hillsides, mangroves and riverbanks, which lack the infrastructure for adequate rainwater drainage or public water supplies and sanitation, and have no regular garbage collection ${ }^{8}$. Local rivers, which were once used for navigation, fishing, and leisure activities, are now a little more than open sewers. The only areas of natural habitat within the municipality are Engenho Pequeno and Guapimirim environmental protection areas, which conserve local mangrove forests. The rest of the municipality consists of urban development, abandoned pastures and small agricultural properties ${ }^{8}$. These local environmental features combine to create optimal conditions for the establishment of a number of diseases, for which snails are the intermediate hosts of the etiological agents.

This study presents the results of a survey of the snail fauna of São Gonçalo, which focused on different types of habitats found in the city's five districts. Species composition and diversity were compared among districts and between freshwater and terrestrial communities. The presence of disease-bearing helminths of relevance to human and animal health among snail specimens was also investigated to determine the possibility of transmission foci within the municipality.

\section{MATERIALS AND METHODS}

\section{Study area}

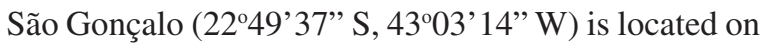
the Eastern margin of Guanabara Bay in the metropolitan region of the city of Rio de Janeiro, with an area of $247.7 \mathrm{~km}^{2}$. São Gonçalo has about one million inhabitants, making it the second most populous municipality in the Brazilian State of Rio de Janeiro, although unplanned and unregulated urban development has resulted in substandard infrastructure, in particular in relation to public sanitation systems. The original vegetation of the municipality was primarily Atlantic Forest and wetlands, although these ecosystems have been greatly altered and only a few protected areas of the natural habitat remain. São Gonçalo has 90 neighborhoods arranged in five districts: Sete Pontes, Centro (downtown), Monjolos, Ipiiba, and Neves (Figure 1). The climate is mesothermal humid, with hot and rainy summers, and mild and dry winters.

\section{Snail collection}

Four collections of terrestrial and limnic snails were carried out at 32 sampling points (Figure 1) in October, November, and December 2013, as well as in January 2014. Terrestrial snails were collected manually in all the districts during the early morning within plots of $6 \mathrm{~m}^{2}$ during 10 minute surveys ${ }^{7}$. Limnic snails were captured using a steel scoop, handled by a single person, who sampled different bodies of water found in each habitat classified as River, Stream, Drainage Ditch, and Sewage Outlet. Snails were placed in containers, and were taken to the Laboratory for Biology and Parasitology of Wild Mammal Reservoirs, at the Oswaldo Cruz Foundation in Rio de Janeiro.

\section{Species identification and diagnosis of parasites}

Limnic snails were counted and measured with a calliper and then placed in polyethylene aquariums $(27.5 \mathrm{~cm} \mathrm{x}$ $12 \mathrm{~cm} \times 13.5 \mathrm{~cm}$ ) containing dechlorinated water. They were fed twice a week with fresh lettuce. Terrestrial snails were also counted and measured with a calliper, and then placed in labeled containers with washed semi-wet sand, and were also fed with fresh lettuce twice a week. For morphological identification, snails were fixed in RaillietHenry solution, according to Fernandez et al. ${ }^{9}$. Terrestrial snails were fixed according to Tomé ${ }^{10}$. The taxonomic identification of snails was carried out by the National Reference Laboratory in Schistosomiasis and Malacology, at the Oswaldo Cruz Foundation in Rio de Janeiro, and the 


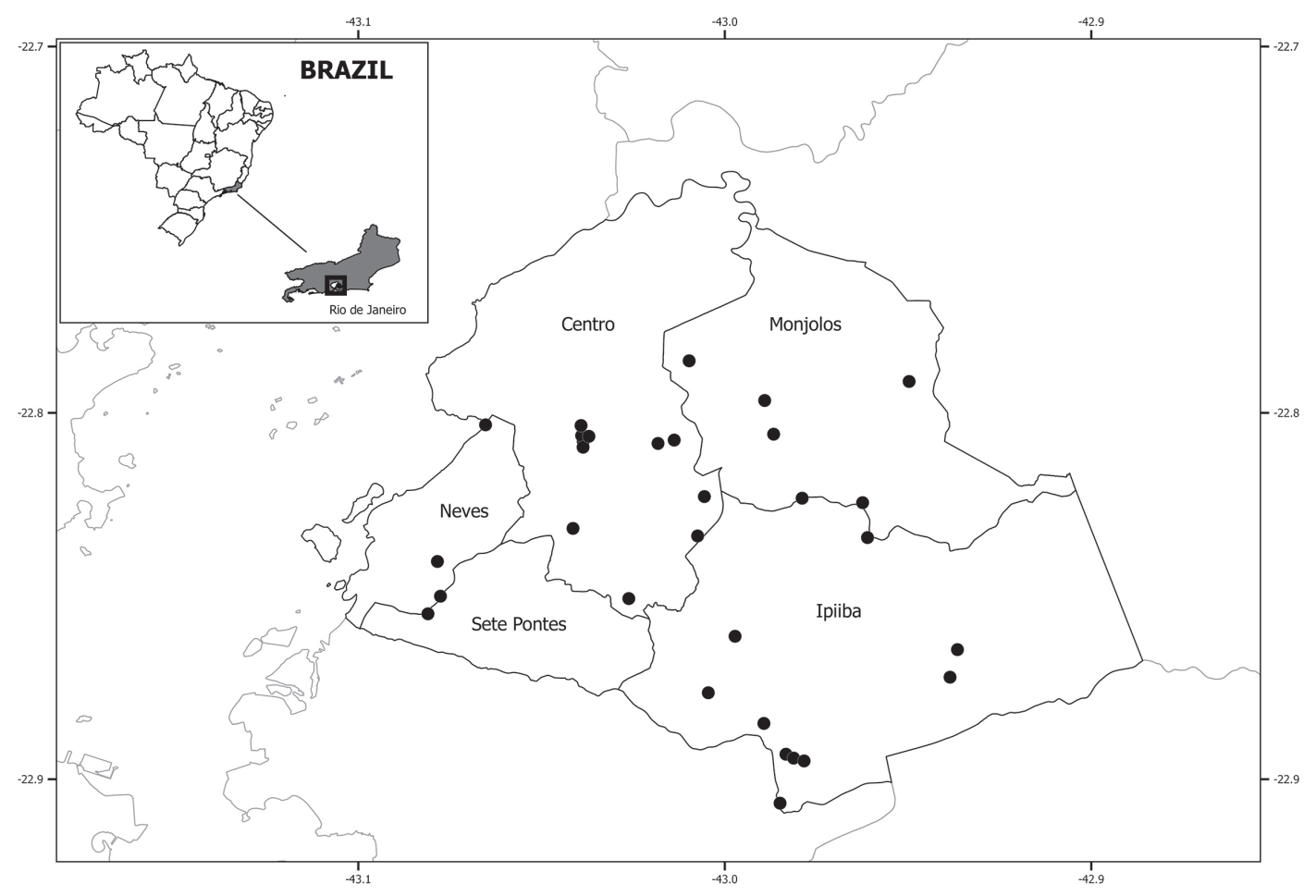

Figure 1 - Study area with the sampling points of the snail survey in São Gonçalo, Rio de Janeiro State, Brazil.

Malacology Laboratory at the National Museum (UFRJ). Snails were dissected and identified using a stereoscopic microscope, and were identified to the species level based on the specialized literature ${ }^{9,11-14}$. They were also submitted to parasitological examination, with limnic snails being placed under artificial light for larvae elimination ${ }^{9}$.

Terrestrial snails were artificially digested using the technique described by Wallace and Rosen. Resulting nematode larvae were analyzed under a stereoscopic microscope ${ }^{15}$. Metastrongylid larvae were identified under an optical microscope according to Moreira et al. ${ }^{16}$. After identification and counting $\mathrm{L}_{3}$ larvae, three Rattus norvegicus (Wistar) were infected with 60 larvae using an orogastric probe (MEDSONDA $5 \mathrm{~mm}$ ) and kept in a vivarium to confirm infection by Angiostrongylus cantonensis. Adult helminths were recovered 45 days after infection and identified by their morphometry, following Anderson et $a l .{ }^{17}$. All the experimental procedures were approved by the Ethics Committee on Animal Use (LW-47/14) of the Oswaldo Cruz Foundation.

\section{Data analysis}

The total abundance of each snail species was considered as the number of specimens collected during the study period, and species richness was the number of species collected. Data were analyzed by district and habitat (and the municipality as a whole), with the limnic and terrestrial communities being considered separately. Species frequency was based on the number of sampling events in which each species was recorded during the study period.

Diversity was compared between sampling points and habitats by the abundance of each species using the ordination technique of Non-Metric Multidimensional Scaling (NMDS) analysis, with the Bray-Curtis similarity index. This analysis was performed using the software PAST 2.10 .

\section{RESULTS}

The community of limnic snails was more diverse and abundant than the terrestrial community. Snails were only found in district 1 (Centro - downtown), and district 2 (Ipiiba), which is a rural area. Snails were found in only nine of the 32 sites surveyed, representing all seven gastropod families. We collected 287 specimens of eight species: Pomacea sp., Melanoides tuberculata (Müller, 1774), Biomphalaria tenagophila (Orbigny, 1835), Dysopeas muibum (Marcus \& Marcus, 1968), Physa marmorata (Guilding, 1828), and Physa acuta (Draparnaud, 1805) in freshwater habitats, and Achatina fulica (Bowdich, 1822) and Bradybaena similaris (Férussac, 1821) in terrestrial habitats (Table 1). B. tenagophila, M. tuberculata, and A. fulica occurred in the largest number 
Table 1 - Snails species, abundance and habitat type in each sampling point in São Gonçalo, Rio de Janeiro State, Brazil

\begin{tabular}{|c|c|c|c|c|c|}
\hline Sampling points & District & Geografic coordinate & Species & Abundance & Habitat \\
\hline 1 & 1 Center & $\begin{array}{l}22^{\circ} 51^{\prime} 33.4 " \mathrm{~S} \\
43^{\circ} 01^{\prime} 46.3 " \mathrm{~W}\end{array}$ & Achatina fulica & 3 & Terrestrial \\
\hline 3 & 2 Ipiiba & $\begin{array}{l}22^{\circ} 53^{\prime} 35.4 " \mathrm{~S} \\
42^{\circ} 58^{\prime} 59.99^{\prime \prime} \mathrm{W}\end{array}$ & Melanoides tuberculata & 13 & Stream \\
\hline 4 & 2 Ipiiba & $\begin{array}{l}22^{\circ} 53^{\prime} 39.2^{\prime \prime S} \\
42^{\circ} 58^{\prime} 52.4 " \mathrm{~W}\end{array}$ & $\begin{array}{c}\text { Achatina fulica } \\
\text { Melanoides tuberculata } \\
\text { Dysopeas muibum }\end{array}$ & $\begin{array}{c}3 \\
37 \\
17 \\
\end{array}$ & $\begin{array}{l}\text { Terrestrial } \\
\text { Stream } \\
\text { Stream }\end{array}$ \\
\hline 5 & 2 Ipiiba & $\begin{array}{l}22^{\circ} 53^{\prime} 42.0^{\prime \prime} \mathrm{S} \\
42^{\circ} 58^{\prime} 42.1 " \mathrm{~W}\end{array}$ & Achatina fulica & 2 & Terrestrial \\
\hline 10 & 1 Center & $\begin{array}{l}22^{\circ} 48^{\prime} 28.0 " \mathrm{~S} \\
43^{\circ} 02^{\prime} 19.1^{\prime \prime} \mathrm{W}\end{array}$ & $\begin{array}{c}\text { Achatina fulica } \\
\text { Bradybaena similaris }\end{array}$ & $\begin{array}{c}37 \\
8\end{array}$ & $\begin{array}{l}\text { Terrestrial } \\
\text { Terrestrial }\end{array}$ \\
\hline 12 & 1 Center & $\begin{array}{l}22^{\circ} 48^{\prime} 33.7^{\prime \prime} \mathrm{S} \\
43^{\circ} 02^{\prime} 19.2 " \mathrm{~W}\end{array}$ & Achatina fulica & 16 & Terrestrial \\
\hline 14 & 1 Center & $\begin{array}{l}22^{\circ} 48^{\prime} 23.0^{\prime \prime} \mathrm{S} \\
43^{\circ} 02^{\prime} 13.5 \prime \mathrm{W}\end{array}$ & $\begin{array}{c}\text { Biomphalaria tenagophila } \\
\text { Physa acuta }\end{array}$ & $\begin{array}{c}104 \\
8\end{array}$ & $\begin{array}{l}\text { Ditch } \\
\text { Ditch }\end{array}$ \\
\hline 17 & 1 Center & - & $\begin{array}{c}\text { Biomphalaria tenagophila } \\
\text { Pomacea sp. }\end{array}$ & $\begin{array}{l}9 \\
2\end{array}$ & $\begin{array}{l}\text { River } \\
\text { River }\end{array}$ \\
\hline 27 & 2 Ipiiba & $\begin{array}{l}22^{\circ} 51^{\prime} 52.6^{\prime \prime} \mathrm{S} \\
42^{\circ} 56^{\prime} 11.4 " \mathrm{~W}\end{array}$ & $\begin{array}{c}\text { Physa marmorata } \\
\text { Biomphalaria tenagophila } \\
\text { Melanoides tuberculata }\end{array}$ & $\begin{array}{c}14 \\
12 \\
2\end{array}$ & $\begin{array}{l}\text { Stream } \\
\text { Stream } \\
\text { Stream }\end{array}$ \\
\hline
\end{tabular}

${ }^{*}$ no snails were found at the other sampling points.

of sites, and B. tenagophila was the most abundant species overall. Species richness was the highest in rivers and streams, habitats with muddy and sandy substrates, where $B$. tenagophila was most frequent.

Four species, A. fulica, B. tenagophila, M. tuberculata, and $P$. marmorata were recorded in $50 \%$ or more of the sampling sites (Table 2), and of these four taxa, $P$. marmorata is the only native species. The other four species were each recorded in only one sampling session, so they were considered accessory species in their respective communities.

Five species were recorded in each of the two districts that had snail populations, Centro (district 1) and Ipiiba (district 2). The NMDS analysis indicated that sampling points 1,10 , and 12 , in district 1 , and point 5 , in district 2 , had the most similar species diversity, because all of them had the terrestrial A. fulica (Figure 2). Points 14 and 17 (district 1) and 27 (district 2) were also similar to one another due to the presence of B. tenagophila and the Physa species. The only native species found were Pomacea sp. in district 1, B. tenagophila in districts 1 and 2 and D. muibum in district 2 .

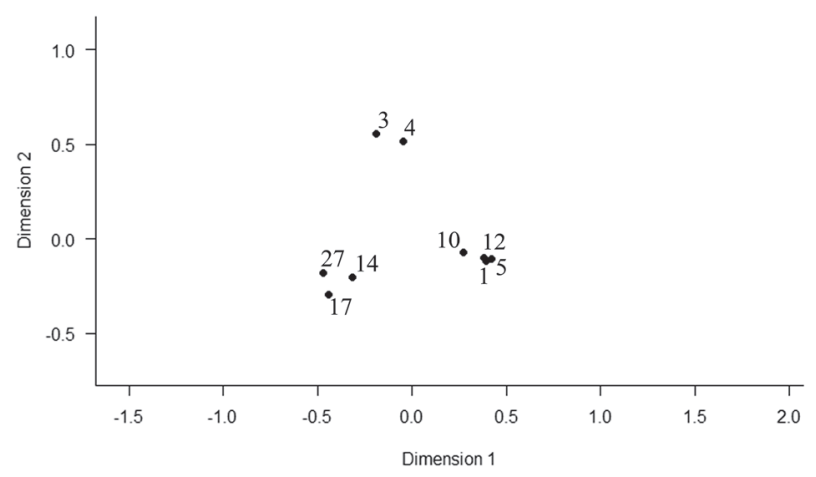

Figure 2 - Diversity analysis of the snail community using nonmetric Multidimensional scaling for each sampling point in São Gonçalo, Rio de Janeiro State, Brazil.

Table 2 - Abundance of each snail species collected in each sampling occasion in São Gonçalo, Rio de Janeiro State, Brazil

\begin{tabular}{lcccccccc}
\hline Month & $\begin{array}{c}\text { Achatina } \\
\text { fulica }\end{array}$ & $\begin{array}{c}\text { Melanoides } \\
\text { tuberculata }\end{array}$ & $\begin{array}{c}\text { Dysopeas } \\
\text { muibum }\end{array}$ & $\begin{array}{c}\text { Bradybaena } \\
\text { similaris }\end{array}$ & $\begin{array}{c}\text { Biomphalaria } \\
\text { tenagophila }\end{array}$ & $\begin{array}{c}\text { Physa } \\
\text { acuta }\end{array}$ & $\begin{array}{c}\text { Pomacea } \\
\text { sp. }\end{array}$ & $\begin{array}{c}\text { Physa } \\
\text { marmorata }\end{array}$ \\
\hline October/2013 & 5 & 21 & 0 & 0 & 0 & 0 & 0 & 0 \\
November/2013 & 34 & 0 & 0 & 0 & 84 & 8 & 0 & 0 \\
December/2013 & 0 & 31 & 0 & 8 & 0 & 0 & 2 & 10 \\
January/2014 & 23 & 0 & 17 & 0 & 41 & 0 & 0 & 4 \\
\hline
\end{tabular}


As expected, the NMDS analysis by habitat indicated that the snail diversity in stream and river habitats was the most similar (Figure 3), although four species were recorded in streams, only two (B. tenagophila and Pomacea sp.) were found in river habitats. In the ditch habitat, only two exotic species were recorded, B. tenagophila (a host of the schistosomiasis trematode) and $P$. acuta. The only species recorded in the terrestrial habitat were A. fulica and $B$. similaris, which are intermediate hosts of the nematode A. cantonensis, the etiological agent of eosinophilic meningitis. No snails were recorded in sewage outlets.

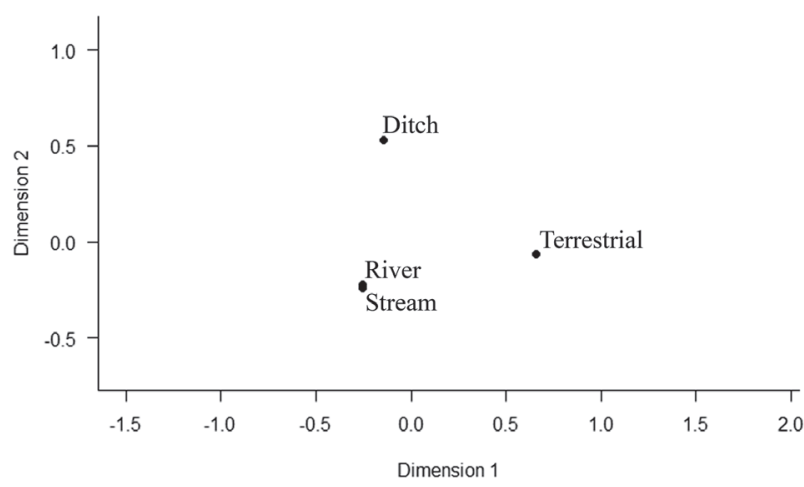

Figure 3 - Diversity analysis of the snail community using nonmetric Multidimensional scaling for each habitat type in São Gonçalo, Rio de Janeiro State, Brazil.

Helminth larvae were only found in A. fulica, however, in eight of 61 specimens (a prevalence of $13.1 \%$ ) being infected by $A$. cantonensis larvae. None of the analyzed limnic species contained helminth larvae.

\section{DISCUSSION}

Only three (D. muibum, B. tenagophila, and Pomacea sp.) of the eight snail species recorded in the present study are considered native, while the other five are exotic. The four most common species recorded in district 1 (downtown) represent a potential problem for public health, given that one of them (B. tenagophila) is an intermediate host of $S$. mansoni, and the other three (A. fulica, B. similaris, and Pomacea sp.) are parasitized by A. cantonensis ${ }^{4,7}$.

The greater diversity and abundance of snails found in rivers and streams with muddy bottoms can be explained by the characteristics of these environments, which provide large amounts of nutrients and retain rainwater, creating favorable conditions for the proliferation of planorbids. These snails can be found in an ample variety of freshwater ecosystems such as lakes, ponds, rivers, streams, irrigation and drainage canals, and most other types of limnic habitats, naturally or artificially flooded ${ }^{2}$.

Achatina fulica, which was one of the most frequent and abundant species, is an exotic snail, originally from Africa, that has adapted well to conditions in Brazil, and is now known to occur in most States ${ }^{18}$. A. fulica is found in a variety of environments, including urban areas, and can be considered an agricultural pest, in addition to representing a risk to public health. The species reproduces rapidly and usually dominates the snail communities in which it occurs $^{19}$. The presence of $A$. cantonensis nematodes in this snail, together with previous records of the occurrence of $A$. cantonensis in both snails $\mathrm{s}^{7}$ and rodent $\mathrm{s}^{20}$ (the definitive hosts of this parasite) in the region of São Gonçalo, emphasize the importance of effective programs implementation to provide sanitary surveillance in this region.

Alterations in limnic environments resulting from urban development and lack of basic sanitation may favor the establishment of schistosomiasis. While none of the specimens of B. tenagophila, which was the most abundant species in the present study, was parasitized by $S$. mansoni, the abundance of this species in the most central areas of the municipality highlights that it is a public health concern.

While Dysopeas muibum was recorded in limnic environments in the present study, it is also considered a terrestrial species ${ }^{21}$. However, the occurrence of this species in streams, unlike reported in the literature, can be attributed to the presence of the exotic snail B. similaris, of the same family, in the terrestrial environment. These two species may have similar ecological characteristics and do not occur together ${ }^{22,23}$. Therefore, the presence of the exotic species $B$. similaris and also of A. fulica may act to exclude D. muibum from their common environment. The same fact may also occur between $P$. acuta and $P$. marmorata. It is possible that these two species compete, given that the former species was only found in ditches, and the later, in streams.

Melanoides tuberculata is the first intermediate host of a number of trematode species ${ }^{24}$. This is an exotic snail, and the invasion of exotic species may be a poorly-estimated cause of emerging infectious diseases ${ }^{24}$. Physa acuta and $P$. marmorata are also exotic species, and the latter is naturally infected by the trematode Echinostoma luisreyi ${ }^{25}$. While none of the prosobranchian snails analyzed in the present study was infected by helminths, A. cantonensis has been recorded in the snail Pomacea lineata in the Brazilian State of Pernambuco ${ }^{4}$. This highlights the importance of these genera as intermediate hosts of parasites that are a major concern for public health.

In comparison with a previous survey (in 2001) in São Gonçalo ${ }^{18}$, the results of the present study indicate a decrease in the number of species occurring in the area, with higher abundances of a few species, which may be excluding species that were previously present in the local snail fauna. In fact, only three of the species recorded 
in the present study (M. tuberculata, B. tenagophila, and $P$. marmorata) were among the 13 species recorded in the 2001 survey. This previous study also recorded Antillorbis norestensis (a native species), Physa cubensis (host of the Fasciola hepatica), Biomphalaria straminea, Biomphalaria schrammi. Gundlachia ticaga (found throughout South America), Lymnacea columela (host of $F$. hepatica), Drepanotrema cimex, Drepanotrema anatinum, Drepanotrema lucidium and Pomacea sordida.

In District 1, three limnic species were found in 2001, A. norestensis, Physa cubensis and B. tenagophila, but only the latter was found in the present study. In district 2 , there were 12 limnic species observed, however, only three were found in the current samplings (P. marmorata, B. tenagophila and M. turbeculatus), and two of them are exotic. In districts 3, 4 and 5, where no snail were observed in the present study, three, two and three species were found respectively in 2001. Although the present survey had a smaller sampling effort than the 2001 study, the presence of only four native species and the reduction of the species richness indicate great changes in species composition between the two sampling periods. The environmental changes exerted influence in the malacological communities, reducing the species richness compared with the previous study. The reduction of species richness may have made some species highly abundant and dominant, such as B. tenagophila and A. fulica, which are the most epidemiologically important species.

The high abundance of A. fulica and the presence of Angiostrongylus larvae in some specimens, as well as the local population density of rodents that act as definitive hosts, underscore the importance of this snail species for public health issues in the municipality. Districts 1 and 2 are most susceptible to the occurrence of infectious diseases, such as schistosomiasis and angiostrongyliasis, due to the presence of the intermediate snail host of the etiological agents of these diseases in these areas. The fact that the most abundant species are exotic and important helminth hosts indicates environmental degradation, changes in the native communities and also the need for monitoring the snail fauna in São Gonçalo in order to prevent possible focal outbreaks of schistosomiasis and angiostrongyliasis.

\section{ACKNOWLEDGMENTS}

We would like to thank Dr. Silvana Carvalho Thiengo and Dr. Lângia Colli Montresor from the National Reference Laboratory in Schistosomiasis and Malacology at the Oswaldo Cruz Foundation in Rio de Janeiro, Dr. Norma Campos Salgado from the Malacology Laboratory at the
National Museum (UFRJ) for the identification of the snail species, and the Oswaldo Cruz Institute at FIOCRUZ for the financial support.

\section{REFERENCES}

1. Martello AR, Nunes IG, Boelter RA, Leal LA. Malacofauna límnica associada à macrófitas aquáticas do Rio Iguariaçá, São Borja, RS, Brasil. Cien Natura. 2008; 30:27- 41.

2. Brasil. Ministério da Saúde. Secretaria de Vigilância em Saúde. Departamento de Vigilância Epidemiológica. Vigilância e controle de moluscos de importância epidemiológica: diretrizes técnicas: Programa de Controle da Esquistossomose (PCE). $2^{\text {a }}$ ed. Brasília: Ministério da Saúde; 2008.

3. Gomes EC, Mesquita MC, Rehn VN, Nascimento WR, Loyo R, Barbosa CS. Urban transmission of schistosomiasis: new epidemiological situation in the forest area of Pernambuco. Rev Bras Epidemiol. 2016;19:822-34.

4. Thiengo SC, Maldonado A, Mota EM, Torres EJ, Caldeira R, Carvalho OS, et al. The giant African snail Achatina fulica as natural intermediate host of Angiostrongylus cantonensis in Pernambuco, northeast Brazil. Acta Trop. 2010;115:194-9.

5. Pilate VJ, Silva LC, Vargas T, Souza BA, Chicarino DE, Bessa EC. Repertório comportamental e horário de atividade do molusco terrestre Dysopeas muibum Marcus \& Marcus, 1968 (Mollusca, Subulinidae) em laboratório. Biofar Rev Biol Farm. 2012;8:176-88.

6. D'ávila S, Dias RJ, Bessa EC, Daemon E. Resistência à dessecação em três espécies de moluscos terrestres: aspectos adaptativos e significado para o controle de helmintos. Rev Bras Zoocien Juiz de Fora. 2004;6:115-27.

7. Oliveira AP, Gentile R, Maldonado Júnior A, Torres EJ, Thiengo SC. Angiostrongylus cantonensis infection in molluscs in the municipality of São Gonçalo, a metropolitan area of Rio de Janeiro, Brazil: role of the invasive species Achatina fulica in parasite transmission dynamics. Mem Inst Oswaldo Cruz. 2015;110:739-44.

8. São Gonçalo. Prefeitura Municipal. Lei Complementar $N^{\circ} 1$, de 22 de julho de 2009. Plano Diretor do município de São Gonçalo; aprova a revisão do Plano Diretor do município de São Gonçalo e dá outras providências. [cited 2018 Jul 30]. Available from: https://leismunicipais.com.br/plano-diretor-sao-goncalo-rj

9. Fernandez MA, Thiengo SC, Amaral RS. Técnicas malacológicas. In: Brasil. Ministério da Saúde. Secretaria de Vigilância em Saúde. Departamento de Vigilância Epidemiológica. Vigilância e controle de moluscos de importância epidemiológica: diretrizes técnicas: Programa de Controle da Esquistossomose (PCE). $2^{\mathrm{a}}$ ed. Brasília: Ministério da Saúde; 2008. p.43-70.

10. Thomé JW. Distensão de moluscos terrestres para fixação, com comentários sobre coleta e transporte. Arq Mus Nacional. 1975;55:153-4. 
11. Thiengo SC, Hayes KA, Mattos AC, Fernandez ML, Cowie RH. A família Ampullariidae no Brasil: aspectos morfológicos, biológicos e taxonômicos. In: Fernandez MA, Santos SB, Pimenta A, Thiengo SC, organizadores. Tópicos em malacologia: ecos do XIX Encontro Brasileiro de Malacologia, III Simpósio sobre Ensino de Malacologia, III Simpósio sobre Malacocultura. Rio de Janeiro: Technical Books; 2011. p.95111.

12. Ohlweiler FP, Takahashi FY, Guimarães MC, Gomes SR, Kawano T. Manual de gastrópodes límnicos e terrestres do Estado de São Paulo associados às helmintoses. Porto Alegre: Redes; 2010.

13. Paraense WL. Physa marmorata Guilding, (1828) (Pulmonata: Physidae). Mem Inst Oswaldo Cruz. 1986;81:459-69.

14. Paraense WL, Pointier JP. Physa acuta Draparnaud, 1805 (Gastropoda: Physidae): a study of topotypic specimens. Mem Inst Oswaldo Cruz. 2003;98:513-7.

15. Wallace GD, Rosen L. Studies on eosinophilic meningitis.V. molluscan hosts of Angiostrongylus cantonensis on the Pacific Islands. Am J Trop Med Hyg. 1969;18:206-16.

16. Moreira VL, Giese EG, Meloa FT, Simões RO, Thiengo SC, Maldonado Júnior A, Santos JN. Endemic angiostrongyliasis in the Brazilian Amazon: natural parasitism of Angiostrongylus cantonensis in Rattus rattus and R. norvegicus, and sympatric giant African land snails, Achatina fulica. Acta Trop. 2013;125:90-7.

17. Anderson RC, Chabaud AG, Willmott S, editors. Keys to the nematode parasites of vertebrates: archival volume. Wallingford: CABI; 2009.

18. Thiengo SC, Fernandez MA, Boaventura MF, Grault CE, Silva HF, Mattos AC, et al. Fresh snails and Schistosomiasis mansoni in the state of Rio de Janeiro, Brazil: I - Metropolitan Mesoregion. Mem Inst Oswaldo Cruz. 2001;96 Suppl:177-4.
19. Simone LR. Land and freshwater molluscs of Brazil: an illustrated inventory on the Brazilian malacofauna, including neighbor regions of the South America, respect to the terrestrial and freshwater ecosystems. São Paulo: EGB: FAPESP; 2006.

20. Simões RO, Monteiro FA, Sanchez E, Thiengo SC, Garcia JS, Costa-Neto SF, et al. Endemic angiostrongyliasis, Rio de Janeiro, Brazil. Emerg Infect Dis. 2011;17:1331-3.

21. Pilate VJ, Silva LC, Bessa EC. Ciclo de vida de Dysopeas muibum (Mollusca, Subulinidae) em laboratório: efeito do isolamento sobre padrões biológicos e conquiliomorfométricos. Iheringia Ser Zool. 2013;103:350-6.

22. Anderson TK, Weaver KF, Guralnick RP. Variation in adult shell morphology and life-history traits in the land snail Oreohelix cooperi in relation to biotic and abiotic factors. J Molluscan Stud. 2007;73:129-37.

23. Poulin, R, Paterson RA, Townsend CR, Tompkins DM, Kelly DW. Biological invasions and the dynamics of endemic diseases in freshwater ecosystems. Fresw Biol. 2011;56:676-88.

24. Santos SB, Braun BS, Magalhães-Fraga SA, Moulton TP. Os moluscos límnicos do Parque Estadual da Pedra Branca: o que nos dizem sobre os rios? In: I Encontro Científico Parque Estadual da Pedra Branca; 2009 Oct 22-23; Rio de Janeiro, Brazil. p.37-9. [cited 2018 Jun 24]. Available from: http://arquivos.proderj.rj.gov.br/inea_imagens/downloads/1_ Encontro_Cientifico_PEPB.pdf.

25. Maldonado Júnior A, Vieira GO, Lanfredi RM. Echinostoma luisreyi n. sp. (Platyhelminthes: Digenea) by light and scanning electron microscopy. J Parasitol. 2003;89:800-8. 